\title{
Implementation of Islamic School Culture Policy in Development of Teacher Professional Performance
}

\author{
Siraj \\ Study Program of Educational Management \\ Postgraduate Program \\ Universitas Negeri Medan \\ Medan, North Sumatera, Indonesia \\ Corresponding email: raj.fisumuslim@gmail.com
}

\author{
Sri Milfayetty \\ Postgraduate Program \\ Universitas Negeri Medan \\ Medan, North Sumatera, Indonesia \\ email: milfayetty@yahoo.com
}

\author{
Ibnu Hajar \\ Postgraduate Program \\ Universitas Negeri Medan \\ Medan, North Sumatera, Indonesia \\ email: dribnu@yahoo.co.id
}

\begin{abstract}
This study is based on the policy of implementing Islamic education in accordance with Aceh Qanun Number 11 of 2014 concerning the implementation of education. The purpose of this study is to find an implementation model of Islamic school culture policy in developing teacher professional performance. This study is a qualitative approach with naturalistic phenomenology and types of multi-site study research. Data collection procedures use in-depth interviews, participant observation, and documentation studies. Data analysis techniques used are data reduction, data presentation, and conclusion drawing. The results of this study found a form of implementation of Islamic school culture policies in the development of professional performance oriented to development: Islamic personality, Islamic values in learning so that the formation of characters, Islamic values in the school environment, teachers professional performance carried out continuously, and synergy and harmonization of internalizing Islamic values. New findings in this study are the importance of religious leadership that has a managerial mechanism that consequently implements the principles of Islamic teachings in carrying out educational policies based on Islamic values. Leadership concept that has a high awareness and commitment in giving birth to generations of the Qur'an and Islamic character.
\end{abstract}

Keywords—Policy, school culture, Islamic, teacher.

\section{INTRODUCTION}

The policy of implementing Islamic education in Aceh is closely related to the historical and socio-cultural factors of the Acehnese people who uphold Islamic values. The implementation of education is based on the fact that the people of Aceh have made local cultural values that cannot be separated from Islamic values. The interaction between Islam and local values cannot be separated from the way humans understand, feel and treat Islam and local values as two inseparable entities. Islam practiced with a touch of local culture is Islam that has been historical and civilized as a result of human reflection and appreciation of local meaning and culture [1]. The Acehnese people make Islam as their identity which is manifested in the form of attitude, mentality, social values and behavior. This is reinforced by the implementation of Islamic law in all aspects of the life of the Acehnese people.

The implementation of education in Aceh at present one of them focuses on the implementation of education based on Aceh's cultural values and the Islamic values. As stipulated in the Aceh Qanun Number 8 of 2014 concerning the Principles of Islamic sharia, and the Aceh Qanun number 11 of 2014 concerning the Implementation of Education which contains Islamic values, Pancasila, and Aceh. This is a form of education reform in Aceh that is closely related to sociopolitical changes, especially the policy of regional autonomy and the implementation of Islamic law [2]. The Qanun mandates that every school is obliged to carry out education based on Islamic values. This proves that education policies at the level of State and Provincial governments are increasing, starting to enter school regulations and entering classrooms, promoting standards and accountability through various mechanisms [3].

Schools in Aceh are unique social systems with different individual cultures and will be integrated into a system based on Islamic values. At the practical level, they complement and complement the values of Islam, the values of Pancasila, and the socio-cultural values of the Acehnese people. Acculturation of these values has shown that typical Indonesian-style Islam is a combination of theological Islamic values with the values of local traditions, culture and local customs [4]. This character of Islam shows the local wisdom of Aceh that does not violate the teachings of Islam, but the presence of Islam can actually synergize with the customs manifested as Islamic school culture. 
Islamic school culture is believed to have a role in producing the best performance for individuals, work groups or school work units. Because an organization will be healthy if it is developed with healthy values derived from religion [5]. Facts on the ground show that there is still a gap between expectations and reality, namely the lack of implementation of Islamic school culture and the professional performance of teachers in high schools in Bireuen District. The problem lies in the ability of the school to understand the concept of education originating from Islamic values, so that the evaluation system is still limited to measuring Islamic symbols; no technical instructions regarding Qanun implementation; and there are still uneven teachers in getting the opportunity to participate in competency and performance improvement programs.

The low professionalism of teachers in Aceh is mainly related to teacher training still running in place, lack of allocation of funds to increase teacher professionalism, a decrease in motivation to develop teacher professionalism competencies, and a lack of teacher skills in mastering technology and information [6].

To overcome the above problems, the specific purpose of this study was to find the implementation form and model of implementation of Islamic school culture policy in the development of compatible teacher professional performance so that it could be used in senior high schools in BireuenAceh.

\section{METHOD}

This study uses a qualitative approach with naturalistic phenomenology. The design in this study uses a multi-site studies [7]. The location of the research at Senior High School (SMA) 1 Bireuen and Senior High School Sukma Bangsa Bireuen. Sources of data in this study are key informan consisting of principals, teachers, school committees, students, parents, and relevant documents according to the research focus.

Data collection procedures use in-depth interviews, participant observation, and documentation studies [8]. Data analysis techniques used are data reduction, data presentation, and conclusion drawing [9]. Trustworthiness is based on four criteria: credibility, transferability, dependability, and confirmability [10].

\section{FINDING AND DISCUSSION}

The results of this study are described based on cross-site analysis to find the form of implementation and implementation model of Islamic school culture policy in the development of professional performance.

The implementation of Islamic school culture policy in developing the professional performance of teachers in SMA Bireuen 1 is a decision made in order to realize the school's ideals, namely excellence in achievement and Islamic character. The school has carried out various Islamic school development activities which include: First, realizing the vision and mission of the Islamic school nuances by empowering all teachers, staff, students, parents, school committees and stakeholders to achieve the goals.

Second, the principal has built up a strong school values and beliefs as a foundation for building Islamic school culture. These values and beliefs have made a major contribution in moving the civilizing process which has a positive impact on the behavior of school citizens. Every teacher, student, staff, parent, and community must understand, appreciate and articulate the values and beliefs of the school to move all school resources in achieving their goals. The findings of this study prove that schools that have superiority are more influenced by the performance of individuals and the organization itself which include values, beliefs, culture, and norms of behavior referred to as the human side of organization [11]. The strategy in internalizing these values and beliefs is done through habituation of behaving and behaving in accordance with Islamic teachings, religious activities, providing facilities and infrastructure, using Islamic symbols, the superior program Tahfizh Al Qur'an, integration of Islamic values in learning and shape character, form a forum for religious activities, study groups in deepening religious understanding, and involve parents and society in shaping Islamic character.

Third, applying Islamic values in work in the form of trust. Amanah is the main value that is believed by the teacher in carrying out his duties and responsibilities professionally so that the formation of a disciplined teacher. The mandate value implies that each individual will be considered good if he can maintain or account for the burden and ability he has received from another party. The mandate value has two dimensions, namely the vertical dimension (to Allah swt) and the horizontal dimension (to fellow humans).

Fourth, carrying out various activities that are oriented towards developing professional performance of teachers. These activities are divided into two types of activities, namely: 1) the activities programmed by the school are intended as a program deliberately carried out by schools such as In House Training; and 2) activities organized by other parties, MGMP, Education and Training, and further studies. The provision of education and training for teachers is carried out with the aim of developing competencies and improving the performance of work responsibilities.

This finding has proven that to be a quality educational institution must carry out strategies by building various school strengths, strengthening school leadership and management, building imagery, developing superior programs, changing the way of thinking of Muslims, and the need for the development of Islamic education in the era of globalization [12]. These strategies must complement each other in building schools through a system that is intact and systematic so that schools remain superior. A strong Islamic school culture that is the core of these six strategies. Islamic school culture is a set of values that underlie behavior, traditions, daily habits, and 
symbols practiced by all residents of SMA 1 Bireuen who are the characteristics, character, and image of the school in the eyes of the Bireuen District community.

The implementation of Islamic school culture policy in the development of professional performance of teachers in the SMA Sukma Bangsa Bireuen starts from the idea of incorporating elements of local Acehnese culture into thoughts and actions based on an understanding of Aceh socio-cultural history experience, in which a long dialectic of culture has taken place. Which allows the development of Acehnese culture which originates from Islam. This finding has proven that as a religion and a transcendent value system, throughout its history, has helped its adherents to understand reality which in turn embodies certain patterns of life view, especially in social and cultural institutions influenced by the outlook on life that. In this context, Islam acts as a subject that determines the course of history, which leads to continuous change and accommodation towards views and patterns of life originating from Islam [13]. Religion gives color and spirit to culture, while culture gives wealth to religion. It can be said that there has been acculturation and accommodation of Islamic teachings with culture, especially the local culture of Aceh. Therefore, SMA Sukma Bangsa in the implementation of Islamic school culture policy in developing professional performance of teachers applies several strategies, namely:

First, a strong commitment in educating the young generation of Aceh as part of educating the life of the nation which leads to the development of quality human resources and revitalization of Acehnese culture. Second, internalization of Islamic values in school culture by accommodating the values and practices of Acehnese local culture with Islamic nuances. Culture is a common habit or pattern of basic assumptions found or developed by certain groups as they learn to deal with problems, adjust to the external environment, and integrate with the internal environment, the basic assumptions have been made good enough to be considered valid, therefore to be able to be taught to new members as the right way to perceive, think, feel in connection with the problems they face [14].

Third, the activities of internalizing Islamic values into school culture by creating a conducive school environment, animating Islamic values in behaving and behaving, Islamic nuances activities, the use of Islamic symbols, as well as the development of academic abilities, skill and morals noble. Fourth, practicing Islamic work culture becomes a habit and driving force that has been entrenched in the lives of school citizens. Five, development using an integrated and holistic approach in changing the behavior of individuals involved in a work process using relevant learning strategies and strategies. These activities are carried out through training, workshops, teacher exchange, In House Training, MGMP, FGBB. Teacher capacity building is carried out in order to strengthen the ability of individuals and organizations to adapt to changes in the environment, as well as strategies to improve the efficiency, effectiveness and responsiveness of performance.
Based on the research findings above, both schools have tried to run an Islamic Aceh education system. The strategies adopted by the two schools are by carrying out various programs and activities in the form of: 1) Islamic personality; (2) Islamic values in learning so that the formation of characters; (3) Islamic values in the school environment; (4) teachers professional performance carried out continuously; and (5) synergy and harmonization of internalizing Islamic values.

This finding strengthens the public policy theory that there are two variables that determine the success of policy implementation, namely: content of policy and context of implementation [15]. Both of these variables characterize the interaction between policy makers, implementing policies and policy users.

Recommended model that can be used as an alternative model for the Aceh government in general and schools in particular in encouraging the implementation of Islamic school culture in the development of teacher professional performance that is continuous improvement, namely sustainable efforts carried out to develop and improve the more effective, efficient Qanun of education implementation and professional. For this reason, the researcher recommends that the quality and professionalism of teachers be encouraged more by increasing specific skills and knowledge regarding

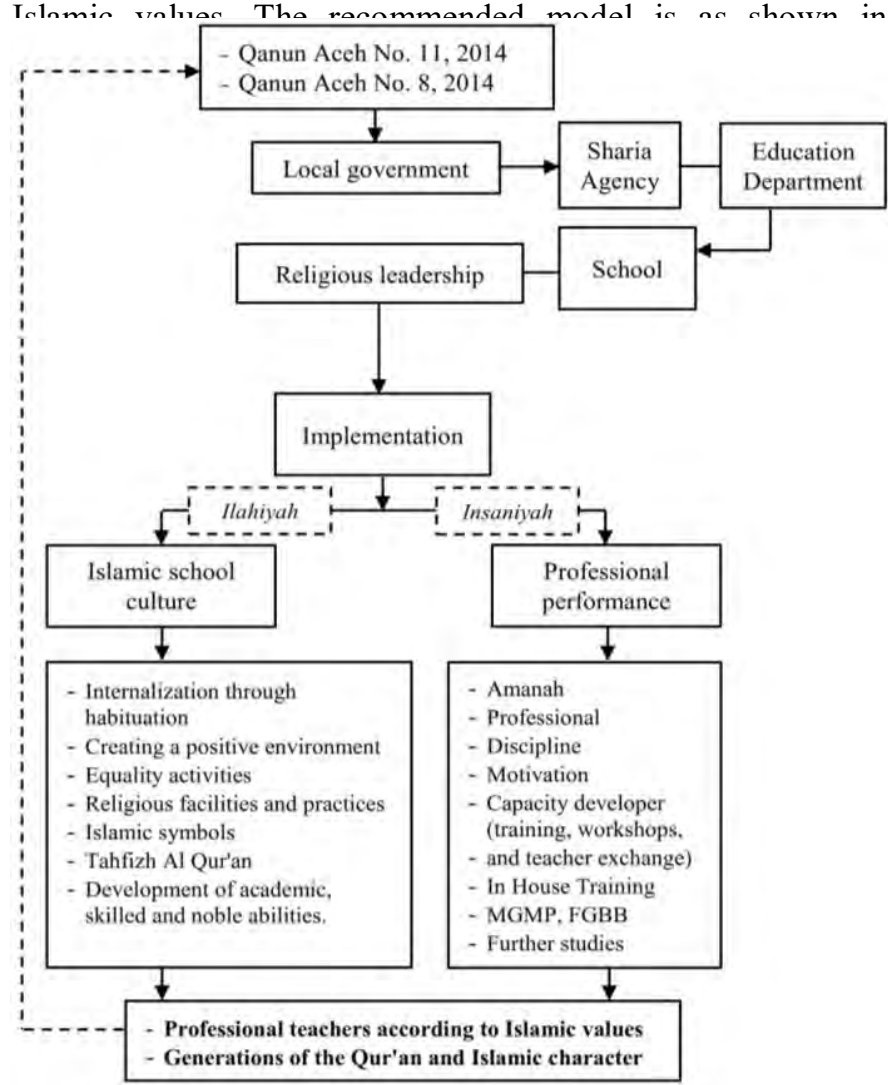

Fig 1. Recommended Model 
New findings in this study are the importance of religious leadership that has a managerial mechanism that consequently implements the principles of Islamic teachings (Habluminallah wa Habluminannas) in carrying out educational policies based on Islamic values. Leadership concept that has a high awareness and commitment in giving birth to generations of the Qur'an and Islamic character.

\section{CONCLUSIONS AND SUGGESTIONS}

The results of this study found a form of implementation of Islamic school culture policies in the development of professional performance oriented to development: (1) Islamic personality; (2) Islamic values in learning so that the formation of characters; (3) Islamic values in the school environment; (4) teachers professional performance carried out continuously; and (5) synergy and harmonization of internalizing Islamic values. Furthermore, the recommendation model was found from the whole process of implementing Islamic school culture policies in developing professional performance of high school teachers in Bireuen District. New findings in this study are the importance of religious leadership that has a managerial mechanism that consequently implements the principles of Islamic teachings (Habluminallah wa Habluminannas) in carrying out educational policies based on Islamic values. Leadership concept that has a high awareness and commitment in giving birth to generations of the Qur'an and Islamic character.

The results of this study can certainly only be carried out on a research scene that has the same character by considering the principle of transferability. Finally, it allows the opening of other research on Islamic school culture policy in developing teacher professional performance.

\section{ACKNOWLEDGMENT}

Acknowledgments are submitted to the Director of Graduate Programs State University of Medan. The Committee of AISTEEL-2018. Finally, thank you to the principals and teachers at senior high school of Bireuen District.

\section{REFERENCES}

[1] G. Saloom, “Akulturasi Islam dan Nilai Lokal dalam Perspektif Psikologi," Kalam: Jurnal Studi Agama dan Pemikiran Islam, vol. 10, 2016, pp. 1-18.

[2] E. Srimulyani, "Islamic Schooling in Aceh: Change, Reform, and Local Context," Studia Islamika, vol. 20, 2013, pp. 467-488.

[3] R. Lowenhaupt, J.P. Spillane and T. Hallett, "Education Policy in Leadership Practice: „Accountability Talk ${ }^{\text {ee }}$ in Schools,” Journal of School Leadership, vol. 26, 2016, pp. 783-810.

[4] S.A. Widodo, "Cultivating Cultural Education Values of Islam Nusantara in MA (Islamic Senior High School) Ali Maksum Krapyak," Jurnal Pendidikan Islam, vol. 5, 2016, pp. 1-20.

[5] D. Hafidhuddin and H. Tanjung, Manajemen Syariah dalam Praktik Jakarta: Gema Insani Press, 2003, p. 30.

[6] Z. Ali Buto, "Pengembangan Kompetensi Profesionalisme Guru PAI di Aceh," Miqot, vol. 9, 2016, pp. 370-389.

[7] R.K. Yin, Case Study Research: Design and Methods, Second Edition. Thousand Oaks, California: SAGE Publications, 2003, p. 13.
[8] R.C. Bogdan and S.K. Biklen, Qualitative Research for Education: An Introduction to Theory and Methods. Boston: Allyn \& Bacon, 1998, p. 119.

[9] M.B. Miles and A.M. Huberman, Qualitative Data Analysis: An Expanded Sourcebook. California: Sage Publications, 1992, p. 12.

[10] Y.S. Lincoln and E.G. Guba, Naturalistic Inquiry. California: SAGE Publications, 1985, p. 289.

[11] R. G. Owens, Organizational Behavior in Education. Boston: Allin and Bacon, 1995, p. 13.

[12] Muhaimin, Pemikiran dan Aktualisasi Pengembangan Pendidikan Islam. Jakarta: Raja Grafindo Persada, 2011, p. 105

[13] A. Azra, Pergolakan Politik Islam. Jakarta: Paramadina, 1996, p. 47.

[14] E.H. Schein, Organizational Culture and Leadership Fourth Edition. San Francisco: Jossey-Bass, 2010, p. 18.

[15] M. S. Grindle, Politics and Policy Implementation in The Third World. New Jersey: Princeton University Press, 1980, p. 9 